\title{
The Evaluation of Innovation Within a Faculty of Arts and Humanities
}

\author{
Fernando Moliní \\ Autonomous University of Madrid \\ Rosa Cañada \\ Autonomous University of Madrid
}

\begin{abstract}
It seems that innovation in the Faculties of Arts and Humanities has seldom been investigated. This research aims to evaluate innovation in the Faculty of Arts and Humanities (FAH) of the Autonomous University of Madrid (AUM). Surprisingly, of the different faculties of AUM, the FAH is the one with a better ratio of publications per researcher and with more teaching innovation projects. In addition to analyzing these statistics, a survey was sent to 544 researchers, of which 205 answered. Most researchers try to be innovative, because $62.2 \%$ take time to think of innovative ideas every week. And they seem innovative because $59.7 \%$ indicate that, in the last three years, they have generated at least one idea that is innovative at an international level. The fact that more than $40 \%$ of the participants do not achieve ideas that are globally pioneering reflects how difficult it is to do so.
\end{abstract}

Keywords: faculty of arts, innovation, university, publications, survey

\section{INTRODUCTION AND THEORETICAL APPROACH}

The university is not the main innovation protagonist, since more innovations are created in the business world than in the university. For some authors the universities, rather than driving the innovative process, are being reluctant actors (Tomas, Castro and Feixas, 2010). For Tate, Campbell-Meier, and Sudfelt (2018) many organizational aspects of universities date back to the Middle Ages and these institutions have an inherent inertia and conservatism.

There are university bureaucrats who do not understand what genuine innovation is and they act against it. For example, bureaucrats who reject Teaching Innovation Projects (TIP) because the documentation does not provide literature to support the idea, when if it is truly original, this is impossible. If, for example, it is proposed to carry out a flipped classroom, there is a very high number of relevant precedents and an abundant literature (such as Hwee, 2019 or He and Zhang, 2018). But if something creative is proposed, which is apparently the first time it is done in the world, there is no possibility of justifying it with bibliographic references. They don't seem to believe that real innovation can happen and discourage those who are trying to do it. Whoever first proposed flipped learning would not have been supported to do so.

But the academic world is not always so excessively immobile. In recent years, the universities have introduced numerous innovations, which in many cases have spread rapidly. The university is dual regarding innovations. Sometimes it is the protagonist of them, while at other times it takes a back seat and adopts them or develops them in an occasional and slow manner. 
This research intends to evaluate innovation in the Faculty of Arts and Humanities (FAH) of the Autonomous University of Madrid (AUM) through, on the one hand, a comparative analysis of the publications of its faculties and schools and of the TIP and, on the other hand, through the analysis of the results obtained from a survey carried out among lecturers and Research Staff in Training (RST). To the best of our knowledge, this is the first analysis of these characteristics.

Researchers and university teachers (all hereafter referred to as researchers) are often surveyed, for example, to evaluate the curriculum or the library, but it is considered that this is the first survey to analyze their innovation globally. There are surveys on specific innovations, mainly on the use of new technologies in teaching (Arshad, Ahmad, \& Ahmad, 2018; Castillo, Larios, \& García, 2010; González-Quiñones, Tarango, \& Fierro-Ramírez, 2018; Shelton, 2014), as well as on teaching innovations (Santos et al., 2017). However, on the evaluation as a whole of all innovative aspects of researchers, there seems to have been a gap so far.

It is assumed that AUM's FAH is relatively innovative in its own way. This is opposed to the fairly widespread opinion that the Humanities teach little useful and practical knowledge, do not generate immediate profits, their graduated students do not have enough professional opportunities, do not have an adequate economic interest, are not very innovative, etc. There have already been many responses to this criticism (e.g. Álvarez, 2018; Barnés, 2020; González, 2017; Nussbaum, 2010; Ordine, 2013), without the controversy having ended. This article focuses on the least addressed complaint, that FAHs are not innovative enough.

\section{METHOD}

The review of the different researchers' publications, the analysis of the TIPs and the results of the survey conducted are the starting point for this study.

\section{Researchers' Publications}

The analysis of publications by each researcher in the different AUM facilities was performed on the basis of the 2017 research reports (UAM_Biblioteca, 2019), which are the latest ones published for the university as a whole at the time this part of the article is written. Only Philosophy and Arts and the Higher Polytechnic School already had the one for 2018. Medicine does not appear because it has not published any at the moment. These reports are produced by the libraries of each facility.

The comparison is not entirely accurate, mainly because different institutions have adopted different criteria, which are not always reflected in their research reports. In particular, some have been able to include or exclude the works of certain teachers, such as emeritus, associates or RST. Information regarding the number of researchers has been homogenized using data from the AUM transparency portal (UAM, 2019a). It does not include associates, emeritus, visiting, honorary, collaborators, or half of the predoctoral RSTs (because it is assumed that in the first two years of doing the thesis they hardly publish). These options mean that the number of lecturers and researchers does not exactly match those published in the reports that provide the data.

The study includes articles, book chapters and books. The congresses are taken into account if they specify the ISBN, DOI, pages or it is said that it is in some proceedings, since it is understood that in these cases they have been published. This may give rise to additional errors, because they may have been published but not reflected in the reports.

Other research merits, such as working papers, reviews, non-scientific articles, forewords, commentaries, reports, doctoral theses, research projects, etc., have not been taken into account. In the Faculty of Law, the eight works carried out by associates have been deducted (in the other centers it can be assumed that they have not been included, but it is not always certain). There are other limitations, such as not analyzing the quality of publications or including reprints. Nevertheless, as a first approximation it seems to be a reasonably valid comparison. 


\section{Teaching Innovation Projects (TIP)}

The number of TIP proposals in the different centers of the AUM, in the 2018-19 academic year, is compared. There are two types, the "innova", which are for teacher innovations in teaching and the "implanta", which are for the consolidation of teaching innovations and improvements developed in the two previous years. To compare the TIPs regarding the number of teachers, their data from 2017 are used, because they are the ones requested by the TIPs of the 2018-19 academic year, which are the ones analyzed here. For the TIPs, information from AUM (UAM, 2019b), which was put into the quality management system, called GeDOC, was used.

\section{Survey}

For the survey, a pilot study was conducted in December 2018 in the Department of Geography and between May and June 2019 all others were surveyed. An e-mail with a link to reply was sent to 544 teachers and RSTs. After the initial mailing and two reminders, 205 replied, an average response rate of $37.7 \%$. Table 1 shows that the highest value reached in one department was $58.3 \%$ and the lowest was $27.1 \%$.

TABLE 1 DEPARTMENTS AND RESPONSE RATE

\begin{tabular}{|c|c|c|c|}
\hline Department & $\begin{array}{c}\text { Teachers } \\
\text { and RST }\end{array}$ & Replies & \% of replies \\
\hline A & 33 & 19 & 57.6 \\
\hline B & 54 & 17 & 31.5 \\
\hline C & 20 & 6 & 30 \\
\hline D & 50 & 15 & 30 \\
\hline E & 34 & 13 & 38.2 \\
\hline F & 46 & 16 & 34.8 \\
\hline G & 31 & 13 & 41.9 \\
\hline H & 36 & 21 & 58.3 \\
\hline I & 38 & 16 & 42.1 \\
\hline J & 48 & 13 & 27.1 \\
\hline K & 51 & 14 & 27.5 \\
\hline L & 16 & 8 & 50 \\
\hline M & 34 & 13 & 38.2 \\
\hline N & 30 & 11 & 36.7 \\
\hline O & 23 & 10 & 43.5 \\
\hline TOTAL & 544 & 205 & 37.7 \\
\hline
\end{tabular}

Source: Developed by the author.

Considering the relatively low reply rate, all the Departments of the Faculty (15) agreed to collaborate in the study. Obtaining 100\% collaboration from the Department Directors reflects a great interest in innovation on their part. Among the factors that have also influenced this success are the following:

- Each Director was promised that they would receive a report regarding innovation in their Department and this was done.

- They were guaranteed that only data from the FAH as a whole or from unidentified Departments would be published.

- How persuasive the e-mails asking them to participate were, although it was not always easy: in 6 Departments one was enough, in 6 two and in 3 three or more.

- They were only asked to have their secretary distribute to teachers and RSTs an e-mail with the link to the survey, as well as two reminders. This could have been done without the 
collaboration of the Departments, because the e-mails of the teaching and research staff are on their Web page, but it was decided to ask for their support in order to measure their degree of interest in innovation and because it involves less work.

In order to find out if there was a relationship between some variables (questions) in the survey that were not multiple-choice, we proceeded to use the nonparametric Chi-square test $\left(\chi^{2}\right)$.

For some investigators, the $38 \%$ response rates obtained in this study are a low percentage. Riba, Torcal and Morales (2010) consider that they should be at least 70\%. O'Rourke (1999) considers that figures of $50-60 \%$ are not enough for many types of research. However, the rate achieved may be considered acceptable in view of the low rates used in many scientific publications, the fact that Internet surveys receive fewer responses, the difficulty of obtaining a high response rate, the general decline in response rate over the years, and recent research concluding that small response rates may be more representative than previously thought. Each of these aspects is discussed below.

Surveys published in scientific journals often obtain response rates of around 50\%. Baruch (1999) studied 175 surveys published in academic journals in different fields and obtained an average response value of 55.6\%. Medway and Fulton (2012) analyze 19 surveys and the average response rate for them was $55.3 \%$. Boser (1988) studies the surveys conducted by 311 university institutions to their students for the evaluation of programs they have taken or to learn about their employment. The level of responses ranged from $10 \%$ to $100 \%$, with an average of $52 \%$. Porter and Umbach (2006) investigate surveys of 321 universities, with an average response rate of $47 \%$.

Sometimes response rates are below 38\%. Larson and Poist (2004) analyzed the 84 mailed surveys for articles published in Transportation Journal between 1992 and 2003. The average response rate for those years was $26 \%$.

Most authors consider that e-mail and Web-based surveys tend to provide worse results than those conducted using other forms (Ardalan, Ardalan, Coppage, \& Crouch, 2007; Denniston et al., 2010; Lin \& Van Ryzin, 2012; Dommeyer, Baum, Hanna, \& Chapman, 2004; Nicholls et al., 2011; Nulty, 2008).

Over the years survey response rates tend to be lower (Fosnacht, Sarraf, Howe, \& Peck, 2017; Larson $\&$ Poist, 2004; Sheehan, 2006). Dey (1997) mentions the case of a survey by the American Council on Education and Cooperative Institutional Research Program, which from 1961 to 1965 had a response rate of $60 \%$ and which has gone from 1987 to 1991 to a response rate of $21 \%$. It can be assumed that most of the decrease in the level of responses is due to a saturation problem (excess of surveys) and perhaps a greater lack of time on the part of the participants, caused, when they are university teachers, because the pressure to publish is much higher, among other reasons.

Fosnacht et al. (2017), in a research referring to university students, conclude that efforts to improve response rates only marginally change the results from a minimum number of responses. According to them, researchers should spend less time trying to improve response rates and more time evaluating and using the data they obtain. Also Lambert and Miller (2014) conclude, referring to surveys of university students that, although response rates are low, the results may be as representative as those of research with much higher rates.

\section{ANALYSIS OF RESULTS}

\section{Researchers' Publications}

Table 2 shows the publications per each researcher in the different centers of the AUM. 
TABLE 2

PUBLICATIONS BY RESEARCHER AT AUM CENTERS

\begin{tabular}{|c|c|c|c|}
\hline Center & Researchers, 2017 & Publications, 2017 & $\begin{array}{c}\text { Publications/ } \\
\text { Researcher }\end{array}$ \\
\hline Higher Polytechnic School & 113.5 & 235 & 2.07 \\
\hline Sciences & 765.5 & 1.172 & 1.53 \\
\hline $\begin{array}{c}\text { Economic and Business } \\
\text { Sciences }\end{array}$ & 214.5 & 254 & 1.18 \\
\hline Law & 208.5 & 514 & 2.47 \\
\hline Arts and Humanities & 393 & 977 & 2.49 \\
\hline $\begin{array}{c}\text { Teacher Training and } \\
\text { Education }\end{array}$ & 133.5 & 202 & 1.51 \\
\hline Psychology & 155 & 245 & 1.58 \\
\hline TOTAL & $1.983,5$ & 3.599 & 1.81 \\
\hline
\end{tabular}

Source: For researchers (UAM 2019a). For publications according to the 2017 research reports (UAM_Library 2019).

With the method used, the Faculty of Arts and Humanities is the one with the highest number of publications per researcher, practically tied with Law. This could be considered an indication that both are particularly innovative, since without bringing something new to the table it is very difficult to publish. In other aspects the FAH is not very innovative, such as in generating patents or start-ups, but in the number of publications it is.

Reale et al. (2018), argue that the predominant methods of research impact assessment in the case of the humanities and social sciences do not sufficiently take into account their value, because they do not consider their specific features, different from those of the natural sciences. According to Donovan and Gulbrandsen (2018), research impact assessment traditionally emphasizes cost-benefit analysis and its economic effects, which does not fit with the humanities.

The AUM average of 1.81 publications per researcher is very high, especially considering that the vast majority of researchers perform teaching tasks and have a considerable lack of resources. This is an indication of the university's high level of academic excellence in terms of the number of publications.

The number of articles per person is one more method of measuring excellence. It is imperfect, like all. For example, there are disciplines in which the articles have far fewer pages, there are much more complicated subjects, it can be more in-depth, more financing may be needed, etc. But to evaluate the production of an institution, it has the advantage that, if there are many co-authors in it, it distorts the comparison less.

There is a movement of researchers called Slow Science that, according to Souto (2019), "aims to value the quality of scientific articles more than their quantity, thus promoting much more reflective and leisurely research." Prioritizing quality over quantity seems very convenient. The pressure of publishing a lot can be contrary to going into depth and handling large and complex projects. On the contrary, it favors superficiality.

The quality of publications has not been evaluated here because it is considered that the usual methods (articles in JCR, number of references, Hirsch $h$-index, etc.) are already very frequently used and, in spite of their interest, are to some extent unfair. Most journals do not publish the percentage of articles they reject. For example, the Social Studies Journal of the Faculty of Social Sciences of the Universidad de los Andes (Colombia), which is a Scopus journal, has done so. In 2017 they rejected 89\% of the articles they received (Universidad de los Andes, n. d.). With these rates (and even if they were much lower, for example, $60 \%$ ), it is perverse to assume that articles not published in JCR or Scopus journals are of poor quality.

There is a very strong pressure to publish in foreign journals of the highest prestige, which are not accessible to most researchers. Moreover, in some fields it can be counterproductive. Neff (2018) indicates that in 2010 in Latindex there were 5,408 Latin American journals, compared to 242 in ISI. The pressure 
to publish in such a minority index leads, according to the author, to not taking risks and, in some fields such as Ecology, to deviate attention from local knowledge needs.

On the other hand, the number of references depends on many factors and may be lower if the article is very innovative, since when opening a new field it is possible that few follow the authors or that they take a long time to do so. There are also many other influencing factors, such as its degree of specialization, whether it is a subject with few researchers, whether it is a fashionable topic, whether it is a compilation, the effectiveness of the publisher in promoting its articles (for example, by making additional suggestions when searching in scientific bibliography databases), etc. ISI (1999), referred to by Salgado and Páez (2007), estimates that in the journals indexed in the Thompson Institute for Scientific Information (ISI) Web of Science, the percentage of articles never cited was between a minimum of $13 \%$ for Immunology and a maximum of $44.5 \%$ for Computer Science. References in different fields should not be compared. Also, within each of them there can be many variations. Likewise, it seems unfair to consider that an uncited (or poorly cited) article is necessarily of poor quality, especially in some subjects.

The pressure of the system to publish in certain journals and to have many references causes researchers unjustified stress and is a serious threat to the health of some of them. By influencing remuneration, promotions, distribution of resources, etc., the system discourages many researches who do not see their work valued, even though an independent tribunal might have considered it to be of very good quality. The value of an article that is of great interest to the society or that is very innovative may be ignored by editorial committees, which often do not give the option of peer review, or be unfairly rejected by a reviewer. Discouragement can lead to giving up and not making an effort, which is exactly the opposite of what is intended with the policy of encouraging a large number of publications in prestigious journals.

\section{Teaching Innovation Projects}

Table 3 lists the TIPs in the different centers of the AUM, in the 2018-19 academic year.

TABLE 3

TEACHING INNOVATION PROJECTS AT THE AUM, ACADEMIC YEAR 2018-19

\begin{tabular}{|l|c|c|c|c|c|}
\hline \multicolumn{1}{|c|}{ Center } & Innova & Implanta & $\begin{array}{c}\text { Total } \\
\text { TIP }\end{array}$ & Lecturers & $\begin{array}{c}\text { Lectures/ } \\
\text { TIP }\end{array}$ \\
\hline Sciences & 28 & 8 & 36 & 632 & 17.56 \\
\hline Economic Sciences & 20 & 6 & 26 & 291 & 11.19 \\
\hline Law & 18 & 2 & 20 & 217 & 10.85 \\
\hline Higher Polytechnic School & 8 & 2 & 10 & 118 & 11.80 \\
\hline Teaching & 12 & 5 & 17 & 212 & 12.47 \\
\hline Arts and Humanities & 29 & 8 & 37 & 392 & 10.59 \\
\hline Psychology & 10 & 2 & 12 & 151 & 12.58 \\
\hline Medicine & 16 & 7 & 23 & 517 & 22.48 \\
\hline Schools of Nursing & 5 & 2 & 7 & & \\
\hline TOTAL & 146 & 42 & 188 & 2.530 & 13.46 \\
\hline
\end{tabular}

Source: UAM (2019a) for staff number of teachers and UAM (2019b) for TIPs.

The center with the most TIP in absolute and relative terms is the FAH. In absolute terms, Science is very close, but it has many more lecturers. In relative terms, after FAH is Law. It is very likely that the Schools of Nursing have a much lower ratio of teachers per TIP than any other center, since they must have very few lecturers, but the source used for the number of lecturers (UAM 2019a) does not consider them, possibly because at that time some were not attached to the AUM. The major centers of the AUM are the 7 Faculties and the Higher Polytechnic School, for which all the data are available. 


\section{Survey}

Regarding the survey, the factors that researchers believe would make them more innovative are:

- "To have more material and human resources", with $73.53 \%$ of the responses. This is largely beyond the faculty and must be vindicated in instances outside the Department. It is a criticism of the university system, in which lecturers lack the necessary means to carry out their work in better conditions. This aspect is consistent throughout the survey. There are complaints about such elementary issues as: there are TIP applications that are not funded; there are waiting lists that are too long for some teacher training courses and many applicants do not take them; there are classrooms without computers and projectors; there are classrooms that lack microphones despite having a large number of students; with respect to research, there is no help for the translation of articles or for the acquisition of some equipment.

- Increase my relationships with other researchers, universities, organizations and innovative companies", with $66.67 \%$ of the responses. This can be done by the lecturers without external help, in other words, by themselves and without depending on the Department, the Faculty, the University or other public administrations. Therefore, it offers more possibilities for improvement in the short term.

- "Receive training on how to be more innovative," with $37.75 \%$ of the responses. This is also outside of the Departments. Possibly, the university should try to offer more general courses on how to be more innovative, which can be applied to teaching, research and management.

- "Reflect more on how to be innovative," with $37.25 \%$ of the responses. It is positive that there are relatively many teachers who are aware of this, even if they are a minority. It has the advantage that they can also do this without outside help.

- "Being less complacent about what I have previously done well," with $21.57 \%$ of responses. It reflects a certain self-criticism.

- "That the Department, Faculty or University have a mailbox to collect innovative ideas", with $20.59 \%$ of the responses. The important thing is not necessarily the mailbox, but the fact that there is an innovation manager to channel them.

In "Others" very relevant responses are given, especially with respect to the need for more time. This is what approximately $29 \%$ of the researchers say. With how tremendously busy university lecturers are, to some extent in bureaucratic tasks, it is difficult to have time to think calmly. The problem of lack of time appears many times in other parts of the survey. On the other hand, several responses emphasize that innovation should be recognized and rewarded. This is also emphasized in other sections of the survey. Also, in this "Others" there are very interesting criticisms and suggestions, for example:

- $\quad$ "To be able to see how other teachers who have recognized innovative experience teach their classes; to exchange experiences and problems with other lecturers in my own area" (the literal answers of anonymous researchers are in quotation marks). One possibility would be to create a teacher training course with teachers (voluntary or compulsory) who have obtained an A (highest grade) in Docentia (Spanish national system for evaluating the quality of teaching), so that students attend 10 hours of class with different teachers, freely chosen by each one. As coursework, each student would have to make an analysis regarding the best and least good aspects of each one of the teachers, as well as the characteristics they have in common.

- $\quad$ If AUM wants to be innovative it must do it well, not half-heartedly: there cannot be teachers who want to innovate and learn how to do it and are not selected in any course of their own program because there are waiting lists."

To the question "Have you ever had an idea about your work that you considered innovative and you have NOT communicated it" $62.07 \%$ answered yes. It indicates that something is going wrong, either at the individual, departmental, faculty, university or, most likely, several at once.

Table 4 shows the reasons for not communicating the innovation. 
TABLE 4

REASONS FOR NOT COMMUNICATING YOUR INNOVATION

\begin{tabular}{|l|c|c|}
\hline \multicolumn{1}{|c|}{ Reason } & Replies & $\%$ \\
\hline There is no adequate channel to communicate it & 49 & 44.14 \\
\hline $\begin{array}{l}\text { I had once communicated an innovative idea and was not taken } \\
\text { seriously enough }\end{array}$ & 45 & 40.54 \\
\hline $\begin{array}{l}\text { Communicating it would have meant more work for me and made } \\
\text { my life more complicated }\end{array}$ & 39 & 35.14 \\
\hline I didn't think it would be well received & 30 & 27.03 \\
\hline Due to shyness or lack of self-confidence & 20 & 18.02 \\
\hline Other & 41 & 36,94 \\
\hline
\end{tabular}

Source: Developed by the author.

$44.14 \%$ of those who had not communicated an innovative idea $(23.9 \%$ of all those responding to the survey), answered that there was no adequate channel for communicating it. This is consistent with the $20.6 \%$ who in a previous question consider that they would be more innovative if the Department, Faculty or University had a mailbox to collect innovative ideas. It seems advisable to have at each administrative level a person responsible for innovative ideas, in charge of channeling them and spreading their existence.

If an innovative idea has ever been communicated and not taken seriously enough, it may have been due to a lack of interest on the part of the idea's recipients or because it may not have been worthwhile. In any case, academic authorities should always reply to the ideas they receive and thank them with kindness. If they are unwilling or unable to implement the proposal, they should explain the reasons, so that the person who sent the proposal feels that it has been well considered, even if it is rejected. Sometimes no answer is given.

The fact that $35.14 \%$ answered that they would have had to work harder and complicate their lives can be explained by the fact that teachers may have an excessive workload (many indicated this in the openended questions) or are poorly motivated.

In "Others" it is important to highlight:

- Several young teachers with precarious employment consider that they do not have adequate status to innovate. This should not be the case, because everyone must innovate from the position they hold, and young people are especially qualified to do so.

- Discouragement because innovation is ignored: "I proposed that the Department's journal be digitalized.... Many people didn't even know what that was, and others 'didn't see a future for my idea' (sic!). On another occasion, even more years ago, I proposed to establish the habit of attending peer classes to exchange experiences or learn other techniques. Awful... Again, to have quarterly seminars between us in order to explain what each of us was researching, give each other ideas, etc. Same result: Nothing." The latter two proposals would be very effective in improving teaching and research. They could be easily adopted, but they are faced with the deep-rooted habit of university teachers to work on an individual basis. The result is that in the end, zero-cost measures that could be very useful are not implemented.

- The lack of information sharing among peers is also mentioned in another proposal: "It is not a topic that is often discussed how each one teaches. I think that if lecturers did as doctors do, who usually meet in assembly every day just to see what has worked and what hasn't with their patients, we teachers would learn a lot from the successes and mistakes of our colleagues."

- Powerlessness because teachers' arguments are ignored, in processes that are excessively rigid. For example, in Docentia: "Claims are a waste of time: if the arguments presented are not in the specifications from which they are based, they are not taken into account... I really don't understand why we are allowed to make up to three claims in Docentia if the arguments are not 
admitted because they are not included in the documentation from which the commission starts."

- The danger of conformism and aging departments: "These types of innovative ideas generally require collective effort and involvement, and in Spanish universities in general the level of inhibition and conformism is beginning to be the standard rather than the exception. Aging departments and with a percentage of components that are there by virtue of inbred, arbitrary and inconsistent selection processes."

$62.19 \%$ answered that they strive to generate a continuous flow of innovative ideas, dedicating time to think about it every week. Without thinking systematically about how we can be more innovative, it is difficult to be more innovative, so the majority saying yes is a very positive result.

When faced with a new problem or challenge, $47.18 \%$ first think for themselves and write down their ideas before turning to other sources, while $52.82 \%$ look at what has already been written about the topic and then write down their ideas. The best answer seems to be the first one, which is in the minority, but by a very small margin. It is possibly the option that can be the most creative, since what others have written influences one's own reasoning and it is then more complicated to come up with different ideas. When we start by thinking for ourselves, we can assume that the vast majority of what we are proposing has already been said before by other authors. However, more original elements may remain and the mind is exercised to a greater degree.

Researchers have more relations with the European Union (66.34\%) and with Spain outside the Autonomous Community of Madrid (61.88\%). It also stands out with other departments of the same university $(56.44 \%)$. To a lesser extent, relations with Spanish-speaking nations $(39.11 \%)$, with other developed non-Spanish-speaking areas of the world (35.64\%) and with the Community of Madrid (34.65\%).

$40.31 \%$ have not generated groundbreaking innovations on an international scale in the last 3 years, $40.31 \%$ from one to two, $11.73 \%$ from three to four, $4.08 \%$ from five to six and $3.57 \%$ more than six. It is very difficult to generate a worldwide innovation and even more difficult to be successful (something that has not been asked), but it is worth trying. The fact that $40.31 \%$ say none reflects that many teachers respond to the survey with great sincerity. On the other hand, $7.69 \%$ say that they have made a large number of groundbreaking innovations on an international scale, five or more. This is perfectly feasible, although they should probably be well known worldwide in their field. If this is not the case, it may be due to several reasons, such as the fact that they do not know how to promote themselves well, that they have not published in other languages or that their innovations are of little relevance.

The survey also had three open-ended questions that are not analyzed here. To the question "Please write down any improvement you would propose to make the Department, Faculty or University more innovative in teaching", $85.8 \%$ of those answering the survey responded. In a similar question, but referring to research, $81.5 \%$ responded, and in another one about management, $72.2 \%$.

With some questions that are not multiple-choice, we have analyzed whether there is an association between these questions and between them and the age and gender of the participants. Pearson's Chi-square test $\left(\chi^{2}\right)$, widely used for categorical variables, was applied. The contingency tables resulting from crossing the frequency distributions of the five variables used show that the Chi-square significance level is greater than 0.05 , a critical level that indicates that there is no significant association between the variables under consideration. For example, it was determined that there is no significant association ( $\mathrm{p}$-value $=0.08$ ) between those who are concerned about generating a continuous flow of innovative ideas, dedicating time to think about it every week, and the number of innovations generated in the last three years, which they consider to be pioneering on an international scale. There is also no relationship between these questions with the age of the respondents ( $p$-value $=0.511$ and $p$-value $=0.160$ ), nor with gender ( $p$-value $=0,906$ and $\mathrm{p}$-value $=0.287$ ). Thus, the results do not indicate that women are more or less innovative than men, nor that one age group generates more innovations than another.

Cross-tabulation of the question Facing a new problem or challenge, the first thing you do is thinking by yourself and writing down your ideas before turning to other sources or looking at what has already been elaborated about the topic and then writing down your ideas, with the question Number of innovations 
that you have generated in the last three years and that you consider to be groundbreaking on an international scale, allows us to affirm the non-significant association between them. The p-value is 0.370 , quite far from the 0.05 threshold, therefore, the null hypothesis of no relationship between them is verified. Crossing these variables with sex and age ( $p$-value $=0.906$ and $p$-value $=307$ respectively) shows that there is no relationship either. In other words, the fact that a person thinks for him/herself and writes down his/her ideas before turning to other sources, or looks at what has already been produced in the field and then writes down his/her ideas, is not related to the number of innovations generated in the last three years, which he/she considers to be groundbreaking on an international scale. Likewise, the age and gender of the respondents did not influence the answers obtained.

\section{DISCUSSION}

\section{Researchers' Productivity}

There are a large number of studies that analyze the productivity of researchers, but almost none offer figures for publications per institution, per researcher and per year, although some of them present data that allow approximate calculations. Those that have been found indicate that the values of 2.49 for AUM's FAH and 1.81 for AUM are very high. However, comparisons always show significant errors because the methodology used is not the same or because it is not possible to know what a comparable figure would be, because the data are not sufficiently justified.

In Spain, the University of Las Palmas de Gran Canaria (2018), provides information that, trying to apply the methodology of this study as much as possible, shows 0.69 publications per researcher. However, this data is clearly underestimated, because associate lecturers have not been deducted and because it only takes into account publications in WoS and Scopus, whereas here all publications are taken into account.

Nebrija University (Spain), in 2017 has a publication per researcher ratio of 1.17 (Nebrija University, n.d.). It is uncertain whether they have included associate lecturers and the entire RST.

The University of Granada (Spain) obtains a very high figure of 1.62 publications per researcher (University of Granada, 2018), especially considering that it only considers what is published in WoS and Scopus. However, there are methodological problems, such as not considering 371 teachers whose professional category is unknown and 61 researchers whose links with the university are also unknown.

Foundation "Conocimiento y Desarrollo" (2018) analyzes, in the SCimago database, the publications of Spanish researchers between 2013 and 2017. The average is 0.72 publications per researcher per year, but again the figure is low because it excludes many other sources.

At the Institute for Research in Applied Mathematics and Systems of the National Autonomous University of Mexico (NAUM), between 1997-2006, its researchers published an average of 1.04 articles per year, without taking into account its 39 academic technicians. NAUM is the institution in Mexico that provides more publications. Between 2000 and 2005, it published 14,528 articles, representing 47.02\% of the national total (Martín and Ortega, 2007).

In a study carried out by the Faculty of Medicine of the NAUM, with data from the period 2000 to 2002, the year with the highest ratio of publications per researcher was 2000, with a ratio of 0.51 (Martínez, Palomares and Piña, 2004).

Peña, Portillo and Caldera (2011) study all the publications of all the researchers of the School of Librarianship and Archival Studies of the University of Zulia (Venezuela), in its 45 years of operation. The results give an average of 0.67 publications per researcher per year.

The scientific production of Colombian social researchers has been analyzed by Masías (2014). The average number of works published during the entire working life is 16.1. Assuming that some researchers start working at 23 years of age and others retire at 65 , it can be calculated that the average research life would be 21 years. In this case, the ratio is 0.77 publications per researcher per year.

Rodríguez and Piedra (2016) evaluate the productivity of 83 communication researchers in Cuba between 2009 and 2014. The average is 1.21 publications per year, but this includes $47 \%$ of works that are contributions to congresses, which in this article have been suppressed, except when they have been published. 
Curiously, measuring quality is easier. If, for example, it is assumed that the highest quality is provided by publishing in journals indexed in the ISI, the annual average per university researcher in Spain in 200304 was 0.5 articles (Fundación C y D, 2006, referred to by Páez and Salgado, 2009).

In some cases it has been concluded that less is published in Spain than in other countries. Reverte et al. (2013), analyze the WoS publications of 373 physical education teachers (265 in Spain and 108 in Brazil). They find that Spanish researchers have an average of 7.49 articles per researcher, while Brazilians have a much higher average of 30.91 articles per researcher. If we consider that the average working life of researchers is 21 years, this would give an average number of publications per year of 0.36 for Spanish teachers and 1.47 for Brazilians. The latter is very high considering that only one database is being considered.

Altbach (1996), mentioned by Smith (2015), estimates that professors at the University of Chicago produce an average of 2.2 publications per year, higher than the AUM average, but lower than AUM's FAH. The data are not comparable because in the case of AUM many different types of teachers are considered, while at the University of Chicago it seems that only professors are considered.

In a study on four of Norway's leading universities, the field of humanities is also the one with the most publications per year, followed by social sciences, technology, natural sciences and medicine. The ratio in humanities is just over 1.60 and the average across all fields is about 0.90 (Rørstad and Aksnes, 2015). The methodology used increase the results because it excludes researchers who do not publish anything and because a publication signed by several authors from the same institution is counted separately for each researcher.

Kastrin et al. (2018) analyze the productivity of researchers in Slovenia between 1970 and 2016. In the case of co-authors, authorship is divided. For example, if there are two, consider that each one has 0.5 publications. The years in which they reach a higher figure is almost two publications per year. It is very high, but it should be taken into account that many types of work are contemplated (such as the publication of abstracts at conferences) and that both university lecturers and non-teaching researchers are included. When co-authorship is not divided, in the years when there are more, the average number of publications per researcher rises to 5, a surprisingly high figure.

These examples are enough to show that comparisons on the number of publications per researcher are very difficult and not very rigorous. In any case, hardly any better results than those of the FAH of AUM have been found. It is most likely that there are more and that they have not been located, but at least the comparisons made indicate that it is a very high number. In this research, it has been preferably searched in the Spanish-speaking environment, considering that it was the most suitable for comparison, but it was not exclusively limited to that context.

\section{Survey}

Moliní and Estrada (2015) applied a questionnaire containing four questions similar to those used in this article. They asked the questions to a Microsoft Ibérica Department, called Microsoft Consulting Services (MCS). Some results are compared below.

At the FAH of AUM, 62.07\% responded that they have ever had an idea about their work that they considered innovative and have not communicated it, while in MCS it happens in $25 \%$. This seems to indicate that the lack of communication may be greater in the FAH than in this private company.

At the FAH of AUM, $62.19 \%$ answered that they strive to generate a continuous flow of innovative ideas, dedicating time to think about it every week. In MCS, this occurs in an average of $36.11 \%$. This seems to suggest that in the FAH there may be a greater effort to be innovative than in that private company.

At the FAH of AUM, 47.18\% answered that when faced with a new problem or challenge, the first thing they do is thinking for themselves and writing down their ideas before turning to other sources. At MCS it is $50 \%$. In both cases it would be convenient that the percentage is higher, because it seems the best strategy in order to be more creative, better than looking at what has already been developed about the topic and then writing the own ideas. 
Table 5 shows the number of innovations that employees have generated in the last three years that they consider to be groundbreaking on an international scale. Results are better in MCS. It seems to indicate that FAH is somewhat less innovative than MCS, but the difference is very small.

TABLE 5

NUMBER OF INNOVATIONS THAT EMPLOYEES HAVE CREATED IN THE LAST THREE YEARS THAT THEY CONSIDER TO BE GROUNDBREAKING ON AN INTERNATIONAL SCALE

\begin{tabular}{|c|c|c|}
\hline International innovations & FAH of AUM & MCS \\
\hline More than 6 & 3.57 & 5.71 \\
\hline 5 to 6 & 4.08 & 5.71 \\
\hline 3 to 4 & 11.73 & 11.43 \\
\hline 1 to 2 & 40.31 & 45.71 \\
\hline None & 40.31 & 31.43 \\
\hline
\end{tabular}

Source: For FAH of AUM, own elaboration; For MCS, Moliní and Estrada (2015) and data provided by the authors.

\section{CONCLUSIONS}

The data regarding publications per person, on Teaching Innovation Projects and those of the survey show a fairly innovative scenario of the FAH of AUM, verifying the starting hypothesis:

- It has the highest rate of publications per researcher per year of the different centers in the university, with 2.5. This is a very high figure on a national and international scale. Basically, in order to publish, it is necessary to offer something new, so having a high number of works is an indication that it is innovative. In addition, the more people publish, the more chances they generate to be creative. However, the comparisons made are highly imprecise and quality criteria should take precedence over quantity.

- It is the AUM center with the highest number of TIPs in absolute and relative terms (per lecturer).

- Innovation is a topic of great interest to all the managers of its 15 Departments, since the directors of all of them have collaborated with the study. With regard to the researchers, only $37.7 \%$, who answered the survey in spite of their multiple tasks, were very interested in innovation. Logically, the fact that many people have not answered more does not mean that they are not interested in innovation. They may not have done so due to lack of time, survey overcrowding or any other cause.

- Most researchers aim to be innovative: $62.2 \%$ of survey respondents state that they strive to create a continuous flow of innovative ideas, spending time thinking about it every week.

- Most researchers claim to be innovators: $59.7 \%$ indicate that they have developed at least one innovative idea in the last 3 years that is groundbreaking on an international scale. The fact that over $40 \%$ did not make it reflects how difficult it is to get a new idea on a global scale.

- It is a Faculty with numerous international and national relationships, but it is also very interconnected with its own university and region.

- Most of the teachers and RSTs who answered the survey have ideas they wish to express. To the open-ended questions "Please write down any improvement you would propose to make the Department, Faculty or University more innovative", $85.8 \%$ answered regarding teaching, $81.5 \%$ regarding research and $72.2 \%$ concerning management.

The survey shows some aspects that can easily be improved, in particular:

- 62.07 of the teachers state that they have ever had an idea related to their work that they considered innovative and have not communicated it. The main reason is that "There is no adequate channel to communicate it" $(44.14 \%$ of those responding to this question, $23.9 \%$ out 
of the total). Perhaps at each administrative level there should be a person in charge of innovation who receives and channels suggestions and also spreads the word about its existence, so that teachers are aware of it. At present in some instances they exist, but it seems that they are not well known.

- To the question "When faced with a new problem or challenge, the first thing you do is": "I think by myself and write down my ideas before turning to other sources" or "I look at what has already been done about the topic and then write down my ideas", the first option, which seems to be the most creative, obtains fewer responses, $47.18 \%$.

A limitation of this research regarding the analysis of publications and TIPs is that only one academic year is studied. It would be appropriate to have other studies to verify whether the patterns detected here are extended over time. In addition, comparisons with other universities have many shortcomings due to the fact that different methodologies have sometimes been used to calculate the data. Concerning the survey, its results could only be compared with another study that used a similar methodology, but referred to the private company instead of the university. This may be due to the fact that it is a groundbreaking type of survey that has so far hardly been applied. In the future it would be very interesting to compare it with other university cases. Additionally, the fact that it is a survey, may raise some doubts regarding the veracity of its results. The fact that more than $40 \%$ of the respondents stated that they had not achieved a single innovation on an international scale in the last three years reflects the honesty of many of them.

The survey to encourage innovation in the university is a simple method to try to improve university creativity. It would be desirable to generalize it to other faculties and universities. But in order for innovation to be truly successful, it is essential that it be institutionalized within the university structure and culture (Bastedo, 2007). This could be done in all faculties and schools with a certain periodicity, for example, every 3 years, and the evolution could be analyzed. Likewise, for innovation to be adopted by a large number of lecturers, it is critical that an environment conducive to change exists in the department, faculty or university (Lefoe and Albury, 2004). Innovations in organizations do not appear by chance; there must be a willingness to intervene (Menanteau-Horta and Marcuello-Servós, 2008).

The survey has been useful for lecturers and RSTs to reflect on innovation, as the mere fact of answering the questions forces them to do so. Finally, a report on the innovation of each Department has been made and $9(60 \%)$ have stated that they would distribute it to all their teachers and RSTs, contributing to the dissemination of the results.

\section{ACKNOWLEDGEMENT}

Translated \& edited by American Publishing Services (https://americanpublishingservices.com/).

\section{REFERENCES}

Alvárez, L.A. (2020). ¿Tienen futuro las carreras de Humanidades? [online]. Retrieved from https://www.elmundo.es/papel/historias/2018/02/21/5a8c6b6c268e3e24178b45ce.html

Altbach, P. (1996). Logan Wilson and the American academic profession. Society, (34), 86-91.

Ardalan, A., Ardalan, R., Coppage, S., \& Crouch, W. (2007). A comparison of student's feedback obtained through paper-based and web-based surveys of faculty teaching. Br. J. Educ. Technol., 38(6), 1085-1101.

Arshad, M., Ahmad, S., \& Ahmad, F. (2018). Social media technologies and their benefits in higher education institutions: A survey of Jazan University. Information Technologies and Learning Tools, 65(3), 92-102.

Barnés, H. (2020). ¿Eliminar carreras de letras para que haya menos parados? España abre el debate [online]. Retrieved from https://www.elconfidencial.com/espana/2020-02-25/menos-carrerasletras-menos-paro-universidad_2468248/

Baruch, Y. (1999). Response rate in academic studies - A comparative analysis. Human Relations, 52(4), 421-438. 
Bastedo, M. (2007). Bringing the State Back In: Promoting and Sustaining Innovation in Public. Higher Education Quarterly, 61(2), 155-170.

Boser, J. (1988). Teacher-education graduate surveys: Variables related to response rates. Journal of Educational Research, 81(6), 369-373.

Castillo, M., Larios, V.M., \& García, O. (2010). Percepción de los docentes de la utilización de las Tecnologías de la Información y la Comunicación. Revista Iberoamericana de Educación, 53(6), $1-10$.

Denniston, M., Brener, N., Kann, L., Eaton, D.K., McManus, T., Kyle, T.M., . . Ross, J.G. (2010). Comparison of paper and pencil versus Web administration of the Youth Risk Behavior Survey (YRBS): Participation, data quality, and perceived privacy and anonymity. Computers Hum. Behav., (26), 1054-1060.

Dey, E.L. (1997). Working with low survey response rates: The efficacy of weighting adjustments. Research in Higher Education, 38(2), 215-227.

Dommeyer, C.J., Baum, P., Hanna, R.W., \& Chapman, K.S. (2004). Gathering faculty teaching evaluations by in-class and online surveys: Their effects on response rates and evaluations. Assessment y Evaluation in Higher Education, 29(5), 611-623.

Donovan, C., \& Gulbrandsen, M. (2018). Introduction: Measuring the impact of arts and humanities research in Europe. Research Evaluation, 27(4), 285-286. doi: 10.1093/reseval/rvy019

Fosnacht, K., Sarraf, S., Howe, E., \& Peck, L.K. (2017). How important are high response rates for college surveys? The Review of Higher Education, 40(2), 245-265.

Fundación Conocimiento y Desarrollo. (2018). Informe CYD 2018 (capítulo 3) [Online]. Retrieved from https://www.fundacioncyd.org/publicaciones-cyd/informe-cyd-2018

Fundación Conocimiento y Desarrollo. (2006). La universidad en España [online]. Retrieved from http://www.fundacioncyd.org/Publicaciones/InformeCyD.asp

González, M.A. (2017). ¿Estamos ante el fin de las humanidades? [online]. Retrieved from https://www.semana.com/educacion/articulo/opinion-la-importancia-de-las-humanidades/535726

González-Quiñones, F., Tarango, J., \& Fierro-Ramírez, L-A. (2018). Identificación de capacidades digitales en estudiantes y docentes universitarios del área de humanidades. Cuadernos de Documentación Multimedia, 29(1), 54-78. doi: 10.5209/CDMU.60542

He, Y., \& Zhang, X. (2018). Innovation Method of Architectural Physics Teaching Based on Flipped Classroom Idea. Educational Sciences: Theory \& Practice, 18(6), 3392-3399. doi:10.12738/estp.2018.6.245

Hwee, J. (2019). Four Pedagogical Dimensions for Understanding Flipped Classroom Practices in Higher Education: A Systematic Review. Educational Sciences: Theory and Practice, 19(4), 14-33. doi:10.12738/estp.2019.4.002

ISI. (1999, January/February). Citations reveal concentrated influences: Some fields have it, but what does it means. Science Watch, pp. 1-2.

Kastrin, A., Klisara, J., Luz, B., \& Povh, J. (2018). Is science driven by principal investigators? Scientometrics, (117), 1157-1182. doi:10.1007/s11192-018-2900-x

Lambert, A.D., \& Miller, A.L. (2014). Lower response rates on alumni surveys might not mean lower response representativeness. Educational Research Quarterly, 37(3), 38-51.

Larson, P.D., \& Poist, R.F. (2004). Improving Response Rates to Mail Surveys: A Research Note. Transportation Journal (American Society of Transportation y Logistics Inc), 43(4), 67-74.

Lefoe, G.E., \& Albury, R. (2004). Integrating innovation into the mainstream in a Faculty of Arts: Obstacles and opportunities [online]. University of Wollongong Research Online, Academic Services Division - Papers. Retrieved from http://ro.uow.edu.au/asdpapers/6

Lin, W., \& Van Ryzin, G.G. (2012). Web and mail surveys: An experimental comparison of methods for nonprof it research. Nonprof it Voluntary Sector, 41(6), 1014-1028.

Martín, E., \& Ortega, S. (2007). La productividad científica en revistas arbitradas de los investigadores del Instituto de Investigaciones en Matemáticas Aplicadas y en Sistemas. Ibersid, (12), 393-400. 
Martínez, F., Palomares, A., \& Piña, E. (2004). Los estándares científicos de productividad en la Facultad de Medicina de la UNAM. Gac. Méd. Méx., 140(6), 599-606.

Masías, R. (2014). Los investigadores sociales en Colombia: Producción, productividad y diferenciación social. Revista Colombiana de Sociología, 37(1), 123-156.

Medway, R.L., \& Fulton, J. (2012). When more gets you less: A meta-analysis of the effect of concurrent web options on mail survey response rates. Public Opinion Quarterly, 76(4), 733-746.

Menanteau-Horta, D., \& Marcuello-Servós, C. (2008). Una perspectiva sociológica para la acción social y el desarrollo: Avances de la Sociocibernética. Revista Austral de Ciencias Sociales, (14), 111124. doi:10.4206/rev.austral.cienc.soc.2008.n14-06

Moliní, F., \& Estrada, E. (2015). La innovación y la importancia de la cercanía o la lejanía: El caso de Microsoft Consulting Services. Scripta Nova, XIX(524), 1-34. doi:10.1344/sn2015.19.15242.

Retrieved from https://revistes.ub.edu/index.php/ScriptaNova/article/view/15242

Neff, M.W. (2018). Publication incentives undermine the utility of science: Ecological research in Mexico. Science and Public Policy, 45(2), 191-201. doi:10.1093/scipol/scx054

Nicholls, K., Chapman, K., Shaw, T., Perkins, A., Sullivan, M.M., Crutchfield, S., \& Reed, E. (2011). Enhancing response rates in physician surveys: The limited utility of electronic options. Health Research and Educational Trust, 46(5), 1675-1682.

Nulty, D.D. (2008). The adequacy of response rates to online and paper surveys: What can be done? Assessment y Evaluation in Higher Education, 33(3), 301-314.

Nussbaum, M. (2010). Sin fines de lucro. Por qué la democracia necesita de las humanidades. Buenos Aires/Madrid: Katz editores.

Ordine, N. (2013). La utilidad de lo inútil. Barcelona: Acantilado.

O'Rourke, T.W. (1999). The importance of an adequate survey response rate and way to improve it. American Journal of Health Studies, 15(2), 107-109.

Peña, D., Portillo, L., \& Caldera, E. (2011). Indicadores de productividad, colaboración y circulación de la investigación. Caso: Escuela de Bibliotecología y Archivología de Luz. Documentación de las Ciencias de la Información, (34), 291-306. Doi:10.5209/rev_DCIN.2011.v34.36459

Páez, D., \& Salgado, J.F. (2009). Indicadores de productividad científica. Implicaciones para la evaluación de la psicología española. Boletín de Psicología, (97), 117-136.

Porter, S.R., \& Umbach, P.D. (2006). Student survey response rates across institutions: Why Do They Vary? Research in Higher Education, 47(2), 229-247.

Reale, E., Avramov, D., Canhial, K., Donovan, C., Flecha, R., Holm, P., . . van Horik, R. (2018). A review of literature on evaluating the scientific, social and political impact of social sciences and humanities research. Research Evaluation, 27(4), 298-308. doi:10.1093/reseval/rvx025.

Reverte, J., Hernández, V., Jové, C., Fonseca, T.J., \& Legaz-Arrese, A. (2013). La productividad científica en WoS y el índice H de Hirsch del área de Educación Física en España y Brasil: Productividad y comparación entre países. Movimiento Porto Alegre, 19(3), 125-147.

Riba, C., Torcal, M., \& Morales, L. (2010). Estrategias para aumentar la tasa de respuesta y los resultados de la Encuesta Social Europea en España. Revista Internacional de Sociología, 68(3), 603-635.

Rodríguez, Y., \& Piedra, Y. (2016). Desempeño de los investigadores de la Comunicación Social en Cuba: estudio de caso de las Universidades de La Habana y Oriente. Período 2009-2014. Razón y Palabra, (92), 1-19.

Rørstad, K., \& Aksnes, D.W. (2015). Publication rate expressed by age, gender and academic position. A large-scale analysis of Norwegian academic staff. Journal of Informetrics, (9), 317-333.

Salgado, J.F., \& Páez, D. (2007). La productividad científica y el índice h de Hirsch de la psicología social española: Convergencia entre indicadores de productividad y comparación con otras áreas. Psicothema, 19(2), 179-189.

Santos, M.A., Jover, G., Naval, C., \& Álvarez, J.L. (2017). Diseño y validación de un cuestionario sobre práctica docente y actitud del profesorado universitario hacia la innovación. Educación XX1, 20(2), 39-71. doi:10.5944/educXX1.19031 
Sheehan, K. (2006). E-mail survey response rates: A review. Journal of Computer-Mediated Communication, 6(2), 1-16.

Shelton, C. (2014). "Virtually mandatory": A survey of how discipline and institutional commitment shape university lecturers' perceptions of technology. British Journal of Educational Technology, 45(4), 748-759. doi:10.1111/bjet.12051

Smith, D.R. (2015). Assessing Productivity Among University Academics and Scientific Researchers. Archives of Environmental \& Occupational Health, (70), 1-3.

Souto, M. (2019). La ciencia necesita tiempo para pensar: el movimiento que quiere acabar con la cultura de "publicar o morir". The Conversation [online]. Retrieved from https://theconversation.com/laciencia-necesita-tiempo-para-pensar-el-movimiento-que-quiere-acabar-con-la-cultura-depublicar-o-morir-116367

Tate, M., Campbell-Meier, J., \& Sudfelt, R. (2018). Organizational routines and teaching innovations: A case study. Teaching in Higher Education, 23(7), 885-901.

Tomás, M., Castro, D., \& Feixas, M. (2010). Dimensiones para el análisis de las innovaciones en la universidad. Propuesta de un modelo. Bordón, 62(1), 139-151.

UAM (Universidad Autónoma de Madrid). (2019a). Portal de transparencias, recursos humanos [online]. Retrieved from https://transparencia.uam.es/recursos-humanos/. The data for 2017 have been provided by Estrella Gayo, head of the Information and Transparency Service.

UAM. (2019b). Programas de formación, innovación docente y movilidad de profesores. Obtained from the platform for quality management GeDOC. Retrieved from https://gedoc.lauam.es/index.php/login

UAM Biblioteca. (2019). Memorias de investigación y publicaciones [online]. Retrieved from $\mathrm{https}$ ://biblioguias.uam.es/produccion/memorias

Universidad de Granada. (2018). Indicadores y estadísticas de investigación UGR 2018 [online]. Retrieved from https://investigacion.ugr.es/ugrinvestiga/pages/cifras.

Universidad de los Andes. (n.d.). La revista [online]. Retrieved from https://revistas.uniandes.edu.co/about/res

Universidad Nebrija. (n.d.). Memoria de Investigación, Indicadores 15-16/16-17 [online]. Retrieved from https://www.nebrija.com/investigacion-universidad/pdf/memoria-indicadores-1617.pdf.

Universidad de las Palmas de Gran Canaria. (2018). Memoria de investigación 2017 [online]. Retrieved from https://www.ulpgc.es/sites/default/files/ArchivosULPGC/vinvestigacion/memoria_de_investigaci on_ulpgc_2017.pdf 